\title{
PERLINDUNGAN HUKUM TERHADAP PENUMPANG PADA TRANSPORTASI UDARA NIAGA PADA BANDARA SULTAN HASANUDDIN MAKASSAR
}

\author{
Ashar Sinilele \\ Pengajar pada Fakultas Syariah dan Hukum UIN Alauddin Makassar
}

\begin{abstract}
In the positive law of Indonesia, there are several laws that provide legal protection to passengers scheduled commercial air transport, among other regulations of Law No. 15 Year 1992 on Flight; OPU Flight Ordinance 1939 or 1939; Government Regulation No. 40 of 1995 Concerning the Air Transport; Government Regulation No. 3 of 2001 on the security and safety of Flight; Law No. 8 of 1999 on Consumer Protection. Air transportation to passengers who feel or losses can file a lawsuit or claim to the airline, the lawsuit or dispute settlement can be reached through two channels, namely the courts and pathways out of court. Both models of dispute resolution are recognized in Act No. 8 of 1999 on Consumer Protection.
\end{abstract}

Keywords:

Legal Protection, Law Flights, Consumer

\begin{abstract}
Abstrak
Dalam hukum positif Indonesia terdapat beberapa peraturan perundang-undangan yang memberikan perlindungan hukum terhadap penumpang transportasi udara niaga berjadwal, peraturan tersebut antara lain Undang-Undang Nomor 15 Tahun 1992 Tentang Penerbangan; Ordonansi Penerbangan 1939 atau OPU 1939; Peraturan Pemerintah Nomor 40 Tahun 1995 Tentang Angkutan Udara; Peraturan Pemerintah Nomor 3 Tahun 2001 Tentang keamanan dan keselamatan Penerbangan; Undang-Undang Nomor 8 Tahun 1999 Tentang Perlindungan Konsumen. Terhadap penumpang transportasi udara yang merasa atau mengalami kerugian dapat mengajukan gugatan atau klaim kepada perusahaan penerbangan, penyelesaian gugatan atau sengketa dapat ditempuh melalui dua jalur yaitu jalur pengadilan dan jalur di luar pengadilan. Kedua model penyelesaian sengketa tersebut diakui di dalam Undang-Undang Nomor 8 Tahun 1999 Tentang Perlindungan Konsumen.
\end{abstract}

Kata Kunci:

Perlindungan Hukum, Undang-undang Penerbangan, Konsumen 


\section{A. PENDAHULUAN}

\section{Latar Belakang}

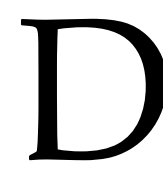
alam era sekarang ini, masyarakat sudah memasuki serta menuju ke arah Transportasi udara niaga dewasa ini mengalami perkembangan pesat, hal tersebut dapat dilihat dari banyak perusahaan atau maskapai penerbangan yang melayani jasapenerbangan ke berbagai rute penerbangan baik domestik maupun internasional, perusahaan atau maskapai penerbangan yang beroperasi dengan menggunakan pesawat terbang. Perusahaan-perusahaan yang melayani jasa penerbangan niaga diantaranya Garuda Indonesia, Merpati, Sriwijaya, Lion Air dan lain-lain.

Penerbangan komersil atau niaga merupakan bentuk transportasi udara yang mengenakan biaya bagi penggunanya. Jenis penerbangan ini dibedakan lagi menjadi dua bentuk, yaitu penerbangan niaga berjadwal dan penerbangan niaga tidak berjadwal. Perkembangan jumlah perusahaan penerbangan di satu sisi menguntungkan bagi para pengguna jasa transportasi udara (penumpang dan pemilik kargo) karena akan banyak pilihan.

Perusahaan-perusahaan tersebut bersaing untuk menarik penumpang sebanyak-banyaknya dengan menawarkan tarif yang lebih murah atau menawarkan berbagai bonus. Namun di sisi lain, dengan tarif yang murah tersebut sering menurunkan kualitas pelayanan service), bahkan yang lebih mengkhawatirkan lagi adalah akan menyebabkan berkurangnya kualitas pemeliharaan (maintenance) pesawat sehingga rawan terhadap keselamatan penerbangan dan akan berdampak kurang baik terhadap keamanan, kenyamanan dan perlindungan konsumen.

Menjamurnya maskapai penerbangan dalam kurun waktu 10 tahun terakhir di satu sisi memberikan implikasi positif bagi masyarakat pengguna jasa penerbangan, yaitu banyak pilihan atas operator penerbangan dengan berbagai ragam pelayanannya. Di samping itu, banyaknya maskapai penerbangan telah menciptakan iklim yang kompetitif antara satu maskapai penerbangan dengan maskapai penerbangan lainya yang pada ujungnya melahirkan tiket murah yang diburu masyarakat secara antusias. Namun, kompetisi ini pada sisi lain juga menimbulkan kekhawatiran bahwa harga tiket murah akan berdampak pada kualitas layanan, khususnya layanan atas perawatan pesawat. Kekhawatiran tersebut muncul akibatnya sering terjadinya kecelakaan pesawat terbang.

Dalam hal ini pengangkut atau maskapai penerbangan berkewajiban untuk mengangkut penumpang dengan aman dan selamat sampai di tempat tujuan secara tepat waktu, dan sebagai konpensasi dari pelaksanaan kewajibannya tersebut maka perusahaan penerbangan mendapatkan bayaran sebagai ongkos penyelenggaran pengangkutan dari penumpang.

Dalam praktik kegiatan transportasi udara niaga sering kali pengangkut tidak memenuhi kewajibannya secara baik dan benar atau dapat dikatakan telah melakukan "wanprestasi". Beberapa kasus atau fakta yang dapat dikategorikan 
sebagai bentuk wanprestasi oleh pengangkut adalah tidak memberikan keselamatan dan keamanan penerbangan kepada penumpang yaitu, berupa terjadinya kecelakaan pesawat yang mengakibatkan penumpang meninggal dunia dan/atau cacat, penundaan penerbangan atau "delay", keterlambatan, kehilangan atau kerusakan barang bagasi milik penumpang, pelayanan yang kurang memuaskan, informasi yang tidak jelas tentang produk jasa yang ditawarkan dan lain-lain.

Setiap kecelakan penerbangan selalu menimbulkan kerugian bagi penumpang yang tentu saja melahirkan permasalah hukum, khususnya berkenaan dengan tanggung jawab 6 R. Subekti, 1995, Aneka Perjanjian, (Bandung: PT Citra Aditya) Hal. 697 Wanprestasi merupakan suatu keadaan dimana debitur (orang berhutang) tidak melaksanakan prestasi sebagaimana mestinya terhadap kreditur sesuai dengan yang telah diperjanjikan perusahaan penerbangan atau pengangkut (carrier) terhadap penumpang dan pemilik barang baik sebagai para pihak dalam perjanjian pengangkutan maupun sebagai konsumen, selain itu persoalan lain bagi konsumen adalah adanya keterlambatan pelaksanaan pengangkutan udara yang terkadang melebihi batas toleransi. Tidak ada upaya hukum yang dapat dilakukan terhadap permasalahan tersebut.

Pada prinsipnya kegiatan pengangkutan udara merupakan hubungan hukum yang bersifat perdata akan tetapi mengingat transportasi udara telah menjadi kebutuhan masyarakat secara luas maka diperlukan campur tangan pemerintah dalam kegiatan pangangkutan udara yaitu menentukan kebijakan-kebijakan atau regulasi yang berhubungan dengan kegiatan pengangkutan udara sehingga kepentingan konsumen pengguna jasa transportasi udara terlindungi. Meskipun perjanjian pengangkutan pada hakekatnya sudah harus tunduk pada pasal-pasal dari bagian umum dari hukum perjanjian Burgerlijk Wetboek (KUH Perdata), akan tetapi oleh undang-undang telah ditetapkan berbagai peraturan khusus yang bertujuan untuk kepentingan umum membatasi kebebasan dalam hal memabuat perjanjian pengangkutan, yaitu meletakkan berbagai kewajiban khusus kepada pihaknya pengangkut yang tidak boleh disingkirkan dalam perjanjian. Berkenaan dengan hal tersebut menurut Sri Redjeki Hartono, negara mempunyai kewajiban untuk mengatur agar kepentingan-kepentingan yang berhadapan harus dapat dipertemukan dalam keselarasan dan harmonisasi yang ideal. Untuk itu, negara mempunyai kewenangan untuk mengatur dan campur tangan dalam memprediksi kemungkinan pelanggaran yang terjadi dengan menyediakan rangkaian perangkat peraturan yang mengatur sekaligus memberikan ancaman berupa sanksi apabila terjadi pelanggaran oleh Ridwan Khairandy, 2006, Tanggung Jawab Pengangkut dan Asuransi Tanggung Jawab Sebagai Instrumen Perlindungan Konsumen Angkutan Udara, (Jakarta: Jurnal Hukum Bisnis Vol 25)

\section{Rumusan Masalah}

Berdasarkan uraian diatas, penulis merumuskan masalah antara lain berikut:

a. Bagaimanakah perlindungan hukum terhadap penumpang pada transportasi 
udara niaga pada Bandara Sultan Hasanuddin Makassar?

b. Upaya apakah ditempuh oleh penumpang yang mengalami kerugian pada Bandara Sultan Hasanuddin Makassar?

\section{Tujuan Penelitian}

Ada beberapa tujuan penelitian ini, yaitu sebagai berikut:

a. Untuk mengetahui bagaimana perlindungan hukum terhadap penumpang transportasi udara niaga pada bandara Sultan Hasanuddin Makassar.

b. Untukm engetahui upaya hukum yang dapat ditempuh oleh konsumen terhadap kerugian yang dialami oleh konsumen pada Bandara Sultan Hasanuddin Makassar?

\section{Manfaat Penelitian}

Penelitian ini diharapkan dapat memberikan kontribusi baik secara teoritis maupun praktis. Secara teoritis, penelitian ini dalam rangka pengembangan ilmu hukum khususnya hukum pengangkutan udara dan hukum perlindungan konsumen. Sedangkan secara praktis penelitian ini diharapkan dapat memberikan kontribusi bagi pihak-pihak yang berkaitan dengan kegiatan pengangkutan udara niaga, antara lain;

a. Pemerintah selaku regulator dalam kegiatan pengangkutan udara khususnya dalam rangka penyusunan kebijakan pemberdayaan konsumen;

b. Perusahaan atau maskapai penerbangan dapat dijadikan sebagai bahan rujukan dalam rangka memberikan pelayanan kepada masyarakat pengguna jasa transortasi udara;

\section{B. TINJAUAN PUSTAKA}

\section{Pengertian Transportasi Niaga}

Pengangkutan sering diganti dengan kata" transportasi". Pengangkutan lebih menekankan pada aspek yuridis sedangkan transportasi lebih menekankan pada aspek kegiatan perekonomian, akan tetapi keduanya memiliki makna yang sama, yaitu sebagai kegiatan pemindahan dengan menggunakan alat angkut yang disebut pesawat.

Dalam buku Abdul Kadir Muhammad mendefenisikan Pengangkutan sebagai proses kegiatan pemindahan penumpang dan/atau barang dari suatu tempat ke tempat lain dengan menggunakan berbagai jenis alat pengangkut mekanik yang diakui dan diatur undang-undang sesuai dengan bidang angkutan dan kemajuan teknologi. Selanjutnya ia menambahkan bahwa pengangkutan memiliki tiga dimensi pokok, yaitu pengangkutan sebagai usaha, pengangkutan sebagai perjanjian dan pengangkutan sebagai proses. ${ }^{1}$

${ }^{1}$ Abdulkadir Muhammad, 1998, Hukum Pengangkutan Niaga, (Bandung: Penerbit Citra Aditya Bhakti). Demikian juga Rustian Kamaludin, Abdulkadir Muhammad, 2007, Arti Penting dan Strategis Multimoda Pengangkutan Niaga di Indonesia, dalam Perspektif Hukum Bisnis di Era Globalisasi Ekonomi, (Yogyakarta: Penerbit Genta Press). 
Pengangkutan sebagai usaha memiliki ciri-ciri sebagai berikut:

1) Berdasarkan suatu perjanjian;

2) Kegiatan ekonomi di bidang jasa;

3) Berbentuk perusahaan;

4) Menggunakan alat angkut mekanik.

Pengangkutan sebagai perjanjian, pada umumnya bersifat lisan (tidak tertulis) tetapi selalu didukung oleh dokumen angkutan. Perjanjian pengangkutan dapat juga dibuat tertulis yang disebut perjanjian carter, seperti carter pesawat udara untuk pengangkutan jemaah haji, carter kapal untuk pengangkutan barang dagang Perjanjian pengangkutan dapat juga dibuat tertulis yang disebut perjanjian carter, seperti carter pesawat udara untuk pengangkutan jemaah haji, carter kapal untuk pengangkutan barang dagangan.

\section{Klasifikasi Transportasi atau Angkutan}

Berbicara tentang transportasi, maka tidak lepas dari berbagai macam bentuknya. Transportasi atau pengangkutan dapat dikelompokan menurut macam atau moda atau jenisnya (modes of transportation) yang dapat ditinjau dari segi barang yang diangkut, dari segi geografis transportasi itu berlangsung, dari sudut teknis serta dari sudut alat angkutannya. Secara rinci klasifakasi transportasi sebagai berikut:

1) Dari segi barang yang diangkut, transportasi meliputi:

a) angkutan penumpang (passanger);

b) angkutan barang (goods);

2) Dari sudut geografis. Ditinjau dari sudut geografis, transportasi dapat dibagi menjadi;

a) Angkutan antar benua: misalnya dari Asia ke Eropah;

b) Angkutan antar kontinental: misalnya dari Francis ke Swiss dan diseterusnya sampai ke Timur Tengah;

c) Angkutan antar pulau: misalnya dari Pulau Jawa ke Pulau Sumatera;

d) Angkutan antar kota: misalnya dari Jakarta ke Bandung;

e) Angkutan antar daerah: misalnya dari Jawa Barat ke Jawa Timur;

f) Angkutan di dalam kota: misalnya kota Medan, Surabaya dan lain-lain.

3) Dari sudut teknis dan alat pengangkutnya, Jika dilihat dari sudut teknis dan alat angkutnya, maka transportasi dapat dibedakan sebagai berikut:

a) Angkutan jalan raya atau highway transportation (road transportation), seperti pengangkutan dengan menggunakan truk, bus dan sedan;

b) Pengangkutan rel (rail transportation), yaitu angkutan kereta api, trem listrik dan sebagainya. Pengangkutan jalan raya dan pengangkutan rel kadangkadang keduanya digabung dalam golongan yang disebut rail and road transportation atau land transportation (angkutan darat);

c) Pengangkutan melalui air di pedalaman (inland transportation), seperti 
pengangkutan sungai, kanal, danau dan sebagainya;

d) Pengangkutan pipa (pipe line transportation), seperti transportasi untuk mengangkut atau mengalirkan minyak tanah, bensin dan air minum;

e) Pengangkutan laut atau samudera (ocean transportation), yaitu angkutan dengan menggunakan kapal laut yang mengarungi samudera;

f) Pengangkutan udara (transportation by air atau air transportation), yaitu pengangkutan dengan menggunakan kapal terbang yang melalui jalan udara.

\section{Fungsi dan Kegunaan Pengangkutan}

Menurut Sri Redjeki Hartono pengangkutan dilakukan karena nilai barang akan lebih tinggi di tempat tujuan daripada di tempat asalnya, karena itu dikatakan pengangkutan memberi nilai kepada barang yang diangkut dan nilai ini lebih besar daripada biaya-biaya yang dikeluarkan. Nilai yang diberikan adalah berupa nilai tempat (place utility) dan nilai waktu (time utility). Nilai tempat (place utility) mengandung pengertian bahwa dengan adanya pengangkutan berarti terjadi perpindahan barang dari suatu tempat, dimana barang tadi dirasakan kurang berguna atau bermanfaat di tempat asal, akan tetapi setelah adanya pengangkutan nilai barang tersebut bertambah, bermanfaat dan memiliki nilai guna bagi manusia, oleh karena itu apabila dilihat dari kegunaan dan manfaatnya bagi manusia, maka barang tadi sudah berambah nilainya karena ada pengangkutan.

\section{Pengertian dan Asas Hukum Pengangkutan}

Mertokusumo memberikan ulasan asas hukum sebagai berikut: "...bahwa asas hokum bukan merupakan hukum kongkrit, melainkan merupakan pikiran dasar yang umum dan abstrak, atau merupakan latar belakang peraturan yang kongkrit yang terdapat dalam dan di belakang setiap sistem hukum yang terjelma dalam peraturan perundang-undangan dan putusan hakim yang merupakan hukum positif dan dapat diketemukan dengan mencari sufatsifat atau ciri-ciri yang umum dalam peraturan kongkrit tersebut Sejalan dengan pendapat Mertokusumo tersebut, Rahardjo berpendapat bahwa asas hukum bukan merupakan peraturan hukum, namun tidak ada hukum yang bisa dipahami tanpa mengetahui asas-asas hukum yang ada di dalamnya, asas-asas hukum memberi makna etis kepada setiap peraturan-peraturan hukum serta tata hukum selanjutnya dipaparkan bahwa asas hukum ia ibarat jantung peraturan hukum atas dasar dua alasan yaitu, pertama asas hukum merpakan landasan yang paling luas bagi lahirnya suatu peraturan hukum. Ini berarti bahwa penerapan peraturan-peraturan hukum itu dapat dikembalikan kepada asas-asas hukum.

Kedua, karena asas hukum mengandung tuntunan etis, maka asas hukum diibaratkan sebagai jembatan antara peraturan-peraturan hukum dengan cita-cita sosial dan pandangan etis masyarakatnya.

Di dalam hukum pengangkutan juga terdapat asas-asas hukum, yang terbagi ke dalam dua jenis, yaitu bersifat publik dan bersifat perdata, asas yang bersifat 
publik merupakan landasan hukum pengangkutan yang berlaku dan berguna bagi semua pihak, yaitu pihak-pihak dalam pengangkutan, pihak ketiga yang berkepentingan dengan pengangkutan, dan pihak pemerintah.

\section{Asas-asas Hukum Pengangkutan Bersifat Publik}

Ada beberapa asas hukum pengangkutan yang bersifat publik, yaitu sebagai berikut:

a. Asas manfaat yaitu, bahwa penerbangan harus dapat memberikan manfaat sebesarbesarnya bagi kemanusiaan, peningkatan kesejahteraan rakyat dan pengembangan perikehidupan yang berkesinambungan bagi warga negara, serta upaya peningkatan pertahanan dan keamanan negara;

b. Asas usaha bersama dan kekeluargaan yaitu, bahwa penyelenggaraan usaha di bidang penerbangan dilaksanakan untuk mencapai cita-cita dan aspirasi bangsa yang dalam kegiatannya dapat dilakukan oleh seluruh lapisan masyarakat dan dijiwai oleh semangat kekeluargaan;

c. Asas adil dan merata yaitu, bahwa penyelenggaraan penerbangan harus dapat memberikan pelayanan yang adil dan merata kepada segenap lapisan masyarakat dengan biaya yang terjangkau oleh masyarakat;

d. Asas keseimbangan yaitu, bahwa penerbangan harus diselenggarakan sedemikian rupa sehingga terdapat keseimbangan yang serasi antara sarana dan prasarana, antara kepentingan pengguna dan penyedia jasa, antara kepentingan individu dan masyarakat, serta antara kepentingan nasional dan internasional;

e. Asas kepentingan umum yaitu, bahwa penyelenggaraan penerbangan harus mengutamakan kepentingan pelayanan umum bagi masyarakat luas;

f. Asas keterpaduan yaitu, bahwa penerbangan harus merupakan kesatuan yang bulat dan utuh, terpadu, saling menunjang, dan saling mengisi baik intra maupun antar modal transportasi;

\section{Asas Hukum Pengangkutan Bersifat Perdata}

Dalam kegiatan pengangkutan terdapat hubungan hukum antara pihak pengangkut dan penumpang, hubungan hukum tersebut harus di dasarkan pada asas-asas hukum. Asas hukum pengangkutan bersifat perdata terdiri dari; sebagai berikut:

a. Asas konsensual yaitu, perjanjian pengangkutan tidak diharuskan dalam bentuk tertulis, sudah cukup dengan kesepakatan pihak-pihak. Akan tetapi, untuk menyatakan bahwa perjanjian itu sudah terjadi atau sudaha ada harus dibuktikan dengan atau didukung dengan dokumen pengangkutan;

b. Asas Koordinatif yaitu, pihak-pihak dalam pengangkutan mempunyai kedudukan yang setara atau sejajar, tidak ada pihak yang mengatasi atau membawahi yang lain. Meskipun pengangkut menyediakan jasa dan melaksanakan perintah penumpang atau pengirim barang, pengangkut bukan bawahan penumpang atau pengirim barang. Pengangkut merupakan salah satu 
bentuk pemberian kuasa.

c. Asas campuran yaitu, pengangkutan merupakan campuran dari 3 (tiga) jenis perjanjian yakni, pemberian kuasa, peyimpanan barang dan melakukan pekerjaan dari pengirim kepada pengangkut. Ketentuan ketiga jenis perjanjian ini berlaku pada pengangkutan, kecuali jika ditentukan lain dalam perjanjian pengangkutan.

d. Asas pembuktian dengan dokumen yaitu, setiap pengangkutan selalu dibuktikandengan dokumen angkutan, tidak ada dokumen pengangkutan berarti tidaka ada perjanjian pengangkutan, kecuali jika kebiasaan yang sudah berlaku umum, misalnya pengangkutan untuk jarak dekat biasanya tidak ada dokumen atau tiket penumpang, contohnya angkutan dalam kota.

\section{Perlindungan Konsumen Pada Transportasi Niaga}

a. Aspek keselamatan penerbangan

Tujuan utama kegiatan penerbangan komersil adalah keselamatan penerbangan. Aspek ini berkaitan erat dengan perlindungan konsumen terhadap pengguna jasa transportasi udara niaga, dalam konteks ini maka semua perusahaan penerbangan wajib untuk mengantisipasi segala kemungkinan yang dapat mencelakakan penumpangnya, oleh karena itu setiap perusahaan penerbangan komersil dituntut untuk menyediakan armada pesawatnya yang handal dan selalu dalam keadaan laik terbang.

Keselamatan penerbangan berkaitan erat dengan fisik pesawat terbang serta aspek pemeliharaan(maintence) sehingga terpenuhi persyaratan teknik penerbangan, selain itu aspek keselamatan penerbangan juga berkenaan erat dengan faktor sumber daya manusia yang terlibat dalam kegiatan penerbangan. Keselamatan penerbangan merupakan hasil keseluruhan dari kombinasi berbagai faktor, yaitu faktor pesawat udara, personil, sarana penerbangan, operasi penerbangan dan badan-badan pengatur penerbangan

b. Aspek Keamanan Penerbangan

Secara fisik aspek keamanan merupakan suatu aspek yang paling terasa oleh konsumen pengguna jasa angkutan udara di samping aspek kecelakaan pesawat udara. Keamanan penerbangan maksudnya adalah aman dari berbagai gangguan, baik secara teknis maupun gangguan dari perampokan, perampasan dan serangan teroris. Dalam aspek keamanan ini perusahaan penerbangan wajib menjamin keamanan selama melakukan penerbangan.

c. Aspek Kenyamanan selama penerbangan Dalam aspek kenyamanan dalam penerbangan, terkandung makna bahwa:

Perusahaan penerbangan komersil wajib memberikan kenyamanan kepada penumpangnya. Aspek kenyamanan penerbangan berkaitan erat dengan kelangkapan pesawat udara seperti tempat duduk, kelengkapan fasilitas, pengatur suhu udara, fasilitas Bandar udara. 
d. Aspek Pelayanan

Bisnis angkutan udara merupakan salah satu bentuk perdagangan jasa, sehingga pelayanan merupakan salah satu indikator sering dijadikan pilihan para calon konsumen, sehubungan dengan hal tersebut aspek pelayanan dalam transportasi udara berkaitan erat dengan prosedur pembelian tiket pesawat dan prosedur penentuan tempat duduk (boarding pass). Dalam konteks ini perusahaan penerbangan harus mengatur dengan baik masalah penentuan tempat duduk bagi penumpang sehingga tidak terjadi tempat duduk yang double yang tentunya sangat merugikan konsumen.

e. Aspek Penentuan Tarif atau Ongkos Penerbangan

Secara sempit tarif merupakan kombinasi dari macam-macam komponen biaya dalam penyelenggaraan pengangkutan udara niaga. Dalam sistem penyelenggaraan transportasi udara niaga terdapat beberapa faktor yang sangat berperan dalam penentuan tarif angkutan, yaitu sistem angkutan udara, kompetisi dan tarif wajar. Sistem angkutan udara system yang berdasarkan pada kebijakan pokok mengenai angkutan udara, yang kemudian menjabarkan kebijakan tersebut dalam bentuk pengaturan mengenai "airline system" di Indonesia, struktur rute-rute penerbangan dan pembinaan industri angkutan udara. Masalah tarif perlu diatur tidak membebankan konsumen.

\section{f. Aspek Perjanjian Angkutan Udara}

Salah satu unsur terpenting dalam rangka memberikan perlindungan konsumen pengguna jasa transportasi udara niaga adalah menyangkut aspek perjanjian pengangkutan.

Dalam konteks ini perusahaan penerbangan berkewajiban untuk memberikan tiket penumpang sebagai bukti terjadi perjanjian pengangkutan udara. Dalam praktinya tiket atau dokumen perjanjian pengangkutan udara telah disiapkan oleh perusahaan dalam bentuk yang telah baku atau biasa dikenal dengan perjanjian standard. Berkenaan dengan telah bakunya dokumen pengangkutan tersebut maka harus adanya jaminan bahwa adanya keseimbangan hak dan kewajiban diantara para pihak, baik pengangkut maupun penumpang.

g. Aspek Pengajuan Klaim

Dalam kegiatan penerbangan sering kali terjadinya risiko kecelakaan yang menimbulkan kerugian bagi penumpang, sehubungan dengan hal tersebut diperlukan perlindungan konsumen bagi penumpang, yaitu adanya prosedur penyelesaian atau pengajuan klaim yang mudah, cepat dan memuaskan91. Prosedur yang mudah berarti bahwa penumpang atau ahli warisnya yang sudah jelas haknya, tidak perlu menempuh prosedur yang berbelit dan rumit dalam merealisasikan hakhaknya. Sedangkan prosedur yang murah berarti para penumpang atau ahli waris yang mengalami kecelakaan tidak perlu mengeluarkan biaya-biaya yang mahal untuk menyelesaikan ganti rugi. Penyelesaian sengketa yang cepat mengandung 
makna bahwa prosedurnya tidak memakan waktu yang lama, dalam kaitan ini dapat menggunakan penyelesaian sengketa di luar pengadilan, sebab biasanya penyelesaian sengketa melalui jalur pengadilan memakan waktu yang lama.

h. Aspek perlindungan melalui asuransi

Pada umumnya perusahaan penerbangan mengasuransikan dirinya terhadap risikorisiko yang kemungkinan akan timbul dalam penyelenggaraan kegiatan penerbangannya, antara lain mengasuransikan risiko tanggung jawab terhadap penumpang. Di samping asuransi yang ditutup oleh perusahaan penerbangan tersebut, di Indonesia dikenal juga asuransi wajib jasa raharja.

\section{METODE PENELITIAN}

\section{Lokasi penelitian}

Penelitian ini menggunakan pendekatan yuridis normatif. Pendekatan normatif dilakukan dengan cara mengkaji ketentuan-ketentuan yang berlaku yang berkenaan dengan kegiatan transportasi udara niaga pada bandara Sultan Hasanuddin Makassar

\section{Teknik Pengumpulan Data}

Data yang digunakan dalam penelitian ini, adalah data sekunder. Pengumpulan data sekunder dilakukan dengan menggunakan metode kepustakaan (library studies) atau dikenal juga dengan nama studi dokumen yaitu antara lain:
a. Undang-Undang Nomor 8 Tahun 1999 Tentang Perlindungan Konsumen.
b. Undang-Undang Nomor 15 Tahun 1992 Tentang Penerbangan;
c. Peraturan Pemerintah Nomor 40 Tahun 1995 Tentang Angkutan Udara
d. Ordonansi Penerbangan 1939 atau OPU 1939;

\section{Metode Pengumpulan Data}

Data yang diperoleh selanjutnya diolah dengan langkah-langkah sebagai berikut:

a) Seleksi data, yaitu pemeriksaan data untuk mengetahui apakah data tersebut sudah lengkap sesuai dengan keperluan penelitian.

b) Klasifikasi data, yaitu menempatkan data sesuai dengan bidang pokok bahasan agar mudah dalam menganalisisnya.

\section{PEMBAHASAN}

\section{Perlindungan Hukum Penumpang Transportasi Udara Niaga pada Bandara} Sultan Hasanuddin Makassar

Transportasi udara selain sebagai sarana migrasi atau perpindahan baik manusia maupun barang-barang, juga sebagai sarana penunjang mobilitas para pelaku bisnis dan perdagangan baik dari di tingkat lokal maupun bisnis internasional. Dipilihyan modal transportasi udara karena jenis moda ini memiliki karekteristik, yaitu mampu mencapai tujuan dalam waktu cepat, menggunakan 
teknologi tinggi, dan memiliki tingkat keselamatan yang tinggi. Akan tetapi dalam kurun waktu beberapa tahun terakhir banyak terdapat peristiwa kecelakaan pada transportasi udara yang memakan atau menimbulkan banyak kerugian baik jiwa maupun harta.

Setiap terjadinya peristiwa kecelakaannya tentunya akan berdampak secara hukum, karena selalu membawa dampak kerugian sehingga melahirkan tanggung jawab hukum.

Dalam hal ini terutama bagi perusahaan penerbangan atau pengangkut (carrier) terhadap penumpang dan pemilik barang, baik sebagai para pihak dalam perjanjian maupun sebagai konsumen. Selain banyaknya kecelakaan pesawat yang berakibat kematian dan cacad, ternyata dalam praktik penyelenggaraan transportasi udara niaga banyak pelanggaran hak-hak penumpang oleh maskapai penerbangan, sehubungan dengan itu perlu adanya penegakan hukum.

\section{a. Undang-Undang Nomor 15 Tahun 1992 Tentang Penerbangan}

Undang-Undang Nomor 15 Tahun 1992 Tentang Penerbangan dimuat dalam Lembaran Negara Tahun 1992 No. 53. Tambahan Lembaran Negara RI No. 3481. Kelahiran Undang-Undang Nomor 15 Tahun 1992 didasari oleh suatu keadaan dimana dunia penerbangan telah mengalami perkembangan yang sangat pesat, sehingga undangundang yang telah ada dianggap tidak sesuai lagi dengan perkembangan jaman.

Selain dalam rangka mengikuti perkembangan zaman, kemajuan ilmu pengetahuan dan teknologi, kelahiran Undang-Undang Nomor 15 Tahun 1992 juga didasari oleh suatu keharusan untuk mentaati hukum internasional di bidang penerbangan sebab Indonesia sebagai salah satu negara anggota Organisasi Penerbangan Sipil Internasional (International Civil Aviation Organization, disingkat ICAO) sebagaimana tercantum dalam konvensi Chicago 1944 beserta Annexes dan dokumen-dokumen teknis operasional serta konvensi-konvensi internasional terkait lainnya, merupakan ketentuan-ketentuan yang harus ditaati sesuai dengan kepentingan nasional.

\section{b. Peraturan Pemerintah Nomor 3 Tahun 2001 Tentang Keamanan dan Keselamatan Penerbangan}

Peraturan Pemerintah Nomor 3 Tahun 2001 dikeluarkan untuk melaksanakan ketentuan dalam Undang-undang Nomor 15 Tahun 1992 tentang Penerbangan, khusunyamengenai keamanan dan keselamatan penerbangan. Di dalam penjelasannya secara jelas dikemukakan kegiatan penerbangan penuh dengan risiko yang sangat tinggi, sekecil apapun kesalahan yang dilakukan oleh pengangkut dapat berakibat fatal, yaitu terjadinya kecelakaan pesawat yang dapat mengakibatkan kerugian bagi penumpang. Oleh karena itulah masalah keamanan dan keselamatan penerbangan mendapat perhatian serius dalam dunia penerbangan, karena menyangkut jiwa manusia. 


\section{c. Tanggung Jawab Perusahaan Pengangkutan Udara Terhadap Penumpang}

Menurut Undang-Undang Nomor 15 Tahun 1992, pengangkut memiliki beberapa tanggung jawab terhadap penumpang, sebagaimana diatur dalam Pasal 43 yang menyatakan:

(1) Perusahaan angkutan udara yang melakukan kegiatan angkutan udara niaga bertanggung jawab atas:

a) kematian atau lukanya penumpang yang diangkut;

b) musnah, hilang atau rusaknya barang yang diangkut;

c) keterlambatan angkutan penumpang dan/atau barang yang diangkut apabila terbukti hal tersebut merupakan kesalahan pengangkut.

(2) Batas jumlah ganti rugi terhadap tanggung jawab pengangkut sebagaimana dimaksud dalam ayat (1) diatur lebih lanjut dengan Peraturan Pemerintah.

Ketentuan mengenai tanggung jawab yang diatur dalam Undang-Undang Nomor 15 Tahun 1992 di atas hanya menentukan bentuk-bentuk tanggung jawab pengangkut sedangkan persyaratan untuk dapat dipertanggungjawabkan, cara penerapannya dan besaran ganti ruginya tidak diatur. Bentuk tanggung jawab perusahaan pengangkutan udara terdiri dari tanggung jawab terhadap kematian atau luka-luka penumpang.

Dalam hukum pengangkutan tanggung jawab ini dikenal dengan tanggung jawab terhadap penumpang. Tanggung jawab berikutnya adalah tanggung jawab terhadap barang.

Mengingat di dalam undang-undang Nomor 15 Tahun 1992 ketentuan tentangtanggung jawab pengangkut hanya bersifat pokok atau umum maka diperlukan aturan-aturan yang lebih jelas dan terinci, dengan demikian diperlukan pengaturan yang bersifat operasional atau secara lebih teknis. Sehubungan dengan itu maka di keluarkanlah Peraturan pemerintah Nomor 40 Tahun 1995 Tentang Angkutan Udara. Pada Pasal 42 PP No 40 Tahun 1995 tersebut, dinyatakan Perusahaan angkutan udara yang melakukan kegiatan angkutan udara niaga berjadwal bertanggung jawab atas:

a) Kematian atau lukanya penumpang yang diangkut;

b) Musnah, hilang atau rusaknya barang yang diangkut;

c) Keterlambatan angkutan penumpang dan/atau barang yang diangkut apabila terbukti hal tersebut merupakan kesalahan pengangkut.

Berdasarkan ketentuan yang terdapat di dalam Undang-Undang Nomor 15 Tahun 1992 dan Peraturan pemerintah Nomor 40 tahun 1995 di atas dapat disimpulkan bahwa ada tiga bentuk tanggung jawab perusahaan angkutan udara niaga, yaitu: Tanggung jawab terhadap penumpang; Tanggung jawab pengangkut terhadap barang dan Tanggung jawab terhadap keterlambatan.

Selanjutnya dari ketiga bentuk tanggung jawab tersebut, adanya perbedaan 
prinsip tanggung jawab pengangkut udara yang dianut, yaitu prinsip tanggung jawab mutlak terbatas (strict liability) dan prinsip tanggung jawab berdasarkan praduga bersalah (rebuttabl presumption of liability principle). Prinsip tanggung jawab mutlak mengandung makna pengangkut akan dikenakan tanggung jawab mutlak tanpa melihat ada atau tidak adanya kesalahan dari pengangkut, perusahaan pengangkut udara harus membayar ganti apabila terjadi kerugian yang dialami penumpang. Dikatakan terbatas karena adanya pembatasan atau limitatif jumlah besarnya ganti rugi yang harus dibayar oleh perusahaan penerbangan.

Tanggung jawab mutlak terbatas ini hanya berlaku bagi kematian atau lukalukanya penumpang dan tanggung jawab terhadap musnah, rusak atau hilangnya barang.

Sedangkan tanggung jawab terhadap keterlambatan berlaku prinsip tanggung jawab berdasarkan praduga bersalah (rebuttable presumption of liability principle). Hal itu berdasarkan rumusan kata-kata adanya unsur kesalahan dari pengangkut. Artinya bahwa pengangkut akan bertanggung jawab apabila keterlambatan terbukti merupakan kesalahan pengangkut.

Dianutnya dua prinsip tanggung jawab pengangkut dalam sistem hukum positifnasional di dalam bidang hukum pengangkutan udara ini tentunya ada alasan-alasan yang melandasinya, yaitu:

1. Kerugian yang diderita akibat keterlambatan lebih kecil jika dibandingkan akibat penumpang meninggal dunia atau luka-luka

2. Kelambatan merupakan pelanggaran kewajiban yang timbul dari perjanjian pada derajat kedua artinya kewajiban tersebut dipenuhi tetapi tidak sebagaimana mestinya dibanding dengan kerugian akibat penumpang meninggal dunia atau luka-luka, kerugian akibat kelambatan lebih sering terjadi dalam pengangkutan udara, sehingga terlalu memberatkan pengangkut bila prinsip tanggung jawab mutlak yang diterapkan.

Dalam Ordonansi Pengangkutan Udara 1939 ketentuan tentang tanggung jawab pengangkut termuat di dalam bab III, bab ini merupakan inti atau pokokpokok dari peraturan ini. Ketentuan mengenai bentuk tanggung jawab perusahaan angkutan udara diatur di dalam Pasal 24, yang menyatakan: (1) Pengangkut bertanggungjawab untuk kerugian sebagai akibat dari luka atau cedera lain pada tubuh, yang diderita oleh seorang penumpang, bila kecelakaan yang mertimbulkan kerugian itu ada hubungannya dengan pengangkutan udara dan terjadi di dalam pesawat terbang atau selama melakukan suatu tindakan dalam hubung- dengan naik ke atau turun dari pesawat terbang. (2) Bila luka tersebut mengakibatkan kematian, maka suami atau istri korban, anak-anaknya atau orang tua yang menjadi tanggungannya, dapat menuntut ganti rugi yang dinilai sesuai dengan kedudukan dan kekayaan mereka yang bersangkutan serta sesuai dengan keadaan.

Menurut ketentuan Pasal 24 OPU di atas ada dua bentuk tanggung jawab pengangkut udara, yaitu tanggung jawab terhadap kematian dan tanggung jawab 
terhadap luka-luka yang dialami penumpang. Pasal ini menganut prinsip bahwa pengangkut selalu bertanggung jawab terhadap kerugian yang dialami penumpang yang mengalami luka-luka atau cidera lain pada tubuh, atau meninggal dunia asalkan syarat-syaratnya terpenuhi, yaitu: adanya kecelakaan(ongeval) yang terjadi, kecelakaan tersebut harus ada hubungannya dengan $105 \mathrm{E}$.

Pengangkutan udara, kecelakaan ini harus terjadi di dalam pesawat terbang atau selama melakukan tindakan dalam hubungan dengan naik ke atau turun dari pesawat terbang. Selanjutnya dalam pasal ini ditentukan pihak-pihak yang dapat melakukan penuntutan jika meninggalnya penumpang yaitu suami atau isteri dari si penumpang, anak-anaknya atau orang tuanya, yang menjadi tanggungan si korban meninggal. Ketentuan ini bersifat limitatif artinya menutup kemungkinan pihak lain untuk mengajukan gugatan. Sedangkan menurut Konvensi Warsawa 1929, para pihak yang dapat melakukan penuntutan adalah ahli waris yang sah dari korban yang meninggal dunia. Dengan demikian, ketentuan menurut ordonansi lebih sempit jika dibandingkan dengan Konvensi Warsawa.

Meskipun peraturan telah menentukan tanggung jawab pengangkut, akan tetapidiperlukan beberapa persyaratan yang harus terpenuhi, agar dapat dilaksanakan. Persyaratanpersyaratan tersebut antara lain:

1. kerugian disebabkan adanya kecelakaan (accident)

2. kecelakaaan tersebut terjadi di dalam pesawat (on board the aircraft)

3. atau terjadi pada saat naik atau turun pesawat (embarkasi atau disembarkasi)

Dalam penjelasan Pasal 43 UU Nomor 15 Tahun 1992 dinyatakan perusahaan penerbangan akan dikenakan tanggung jawabnya apabila kematian atau lukanya penumpang diakibatkan karena kecelakaan selama dalam pengangkutan udara dan terjadi di dalam pesawat udara atau kecelakaan selama dalam pengangkutan udara dan terjadi di dalam pesawat udara atau kecelakaan pada saat naik ke atau turun dari pesawat udara. Termasuk dalam pengertian lukanya penumpang adalah cacat fisik dan/atau cacat mental. Dari penjelasan di atas yang harus dipahami adalah kriteria kecelakaan, sebab undang-undang tidak menentukan dengan jelas pengertian kecelakaan. Untuk memperoleh gambaran mengenai apa yang dimaksud dengan kecelakaan tentunya harus merujuk pada sumber-sumber yang lain, antara lain peraturan teknis, pendapat para ahli dan putusan pengadilan.

d. Persyaratan Berlakunya Tanggung Jawab Perusahaan Pengangkutan Udara Sebagai Pengangkut

Dalam menentukan tanggung jawab pengangkut diperlukan beberapa persyaratan, dengan demikian tidak semua kerugian penumpang dapat dimintakan ganti rugi, hanya kerugian-kerugian yang memenuhi persyaratan saja yang akan diganti rugi. Persyaratanpersyaratan tersebut sebagai berikut:

e. Adanya Kecelakaan Pesawat Terbang

Sebagaimana telah dikemukakan sebelumnya bahwa adanya kecelakaan 
merupakan syarat dapat diterapkannya tanggung jawab bagi pengangkut, itu artinya perlu dibahas tentang kecelakaan pesawat. Menurut Annex 13 Konvensi Chicago 1944 dikenal dua pengertian kecelakaan pesawat udara, yaitu kecelakaan (accident) dan kejadian (incident) kedua pengertian tersebut memiliki perbedaan makna. Kecelakaan (accident) adalah suatu peristiwa yang terjadi di luar dugaan manusia yang berhubung dengan pengoperasian pesawat udara yang berlangsung sejak penumpang naik pesawat udara (boarding) dengan maksud melakukan penerbangan ke tempat tujuan sampai semua penumpang turun(dembarkasi) dari pesawat di bandar udara. Peritiwa kecelakaan menyebabkan orang meninggal dunia atau luka parah, luka ringan, luka tetap maupun sementara yang diakibatakan:

a) Benturan dengan pesawat udara

b) Kontak langsung dengan bagian pesawat udara atau

c) Terkena hempasan langsung mesin jet pesawat udara atau

Sedangkan pengertian kejadian atau insiden pesawat terbang adalah peristiwa selain kecelakaan yang terjadi selama penerbangan berlangsung yang berhubungan dengan pengoperasional yang dapat membahayakan keselamatan penerbangan (Annex 13 Konvensi Chicago 1944). Sedangkan Dalam Lampiran Keputusan Menteri Perhubungan Nomor 11 Tahun 2004 Tentang pemberitahuan dan pelaporan kecelakaan, kejadian atau keterlambatan kedatangan pesawat udara dan prosedur penyelidikan kecelakaan/kejadian pada pesawat udara106.

Pengertian kecelakaan pesawat udara adalah suatu peristiwa yang berhubungan dengan pengoperasian pesawat udara yang berlangsung dalam kurun waktu sejak seseorang naik pesawat udara dengan maksud ikut dalam penerbangan sampai dengan semua orang turun dari 106 Peraturan ini merupakan peraturanperaturan keselamatan penerbangan sipil bagian 830, yang isi mengadopsi ketentuan Konvensi Chicago 1944 pesawat, dan apabila terdapat orang yang meninggal dunia atau terluka parah, atau bila pesawat udara mengalami kerusakan berat. Pengertian kecelakaan yang di atur didalam keputusan menteri ini hampir sama dengan pengertian yang terdapat di dalam Annex 13 Konvensi Chicago 1944.

Sedangkan menurut pakar hukum penerbangan, E. Suherman107 defenisi kecelakaan adalah suatu kejadian yang menimbulkan kerugian pada penumpang, baik sehingga ia tewas atau luka-luka, dan terjadi selama penumpang berada dalam pengawasan pengangkut udara atau pegawainya dan kejadian itu harus ada hubungannya dengan pengangkutan udara. Senada dengan itu menurut Endang Saefullah108 kecelakaan adalah suatu kejadian luar biasa yang tidak diharapkan atau tidak dapat diperkirakan sebelumnya oleh pihak korban. Rumusan ini jauh lebih tepat dan luas dengan disertai kualifikasi tertentu sehingga tidak semua kejadian dapat dikatakan sebagai kecelakaan.

Dalam praktik penyelenggaraan pengangkutan udara niaga, penumpang sering mengeluhkan pelayanan yang diberikan oleh maskapai penerbangan terhadap barang-barangnya yaitu seringnya terjadi kehilangan barang bagasi, kerusakan 
barang, tertukar dan lain-lain. Fakta-fakta kerugian-kerugian yang dialami oleh penumpang tersebut dalam perspektif hukum merupakan salah satu bentuk pelanggaran hukum, menurut hukum salah satu tanggung jawab pengangkut adalah bertanggung jawab terhadap barang penumpang sebagaimana dinyatakan dalam pasal 43 UU No 15 Tahun 1992 dan Pasal 42 Peraturan Pemerintah Nomor40 Tahun 1995, yang menyatakan perusahaan angkutan udara niaga bertanggung jawab atas kerusakan, hilang atau musnahnya barang. Ordonansi Pengangkutan udara 1939 juga mengatur mengenai tanggung jawab pengangkut terhadap barang, yaitu Pasal 25 yang menyatakan:

(1) Pengangkut bertanggung jawab untuk kerugian yang timbul sebagai akibat dari kehancuran, kehilangan atau kerusakan bagasi atau barang, bila kejadian yang menyebabkan kerugian itu terjadi selama pengangkutan udara.

(2) Pengangkutan udara seperti yang dimaksud oleh ayat yang lain, meliputi juga waktu bagasi atau orang yang berada di bawah pengawasan pengangkut, baik di lapangan terbang atau di mana saja dalam hal pendaratan di luar Suatu lapangan terbang udara tidak meliputi pengangkutan di darat, laut atau (3) Waktu pengangkutan udara tidak meliputi pengangkutan di darat, laut atau sungai yang dilaksanakan di luar lapangan terbang. Akan tetapi bila peng angkutan semacam itu dilakukan untuk melaksanakan suatu perjanjian pengangkutan udara dalam hubungan dengan pemuatan, penyerahan atau pemindahan muatan, maka pengangkut bertanggungiawab untuk semua kerugian, seakan-akan kerugian ini timbul sebagai akibat dari suatu kejadian selama pengangkutan udara, kecuali bila pengangkut dapat membuktikan, bahwa kerugian itu adalah kejadian yang tidak terjadi selama pengangkutan udara.

\section{f. Tanggung Jawab Perusahaan Pengangkutan Udara terhadap Keterlambatan Penerbangan}

Secara harfiah keterlambatan berarti tidak tepat atau tidak sesuai dengan waktu yang telah ditetapkan, atau dapat juga diartikan kemunduran jadwal. Dikaitkan dengan kegiatan penerbangan, maka dapat dikemukakan bahwa keterlambatan penerbangan (delay) adalah suatu keadaan dimana penerbangan tidak sesuai dengan waktu keberangkatan pesawat dari Bandar udara menuju Bandar udara tujuan. Keterlambatan penerbangan tentunya akan menimbulkan konsekuensi bagi penumpang antara lain: akan terlambat tiba di tempat tujuan, harus menunggu hingga diberangkatkan. Keterlambatan penerbangan bersifat paradoksal dengan tujuan penerbangan yaitu cepat tiba ditujuan.

Keterlambatan penerbangan sampai dengan saat ini masih menjadi persoalan dalam kegiatan penerbangan, masalah ini banyak mendapat perhatian dari berbagai pihak, persoalan ini sering dikeluhkan oleh konsumen. Padahal alasan utama konsumen menggunakan jasa penerbangan adalah karena ketepatan waktu tiba di tempat tujuan. 
Keluhan-keluhan konsumen berkenaan dengan keterlambatan penerbangan ini banyak di jumpai dimedia massa baik cetak maupun elektonik.

Dengan demikian, apabila masih ada perusahaan penerbangan yang mencantumkan klausula baku yang membatasi tanggung jawabnya maka hal tersebut bertentangan dan batal demi hukum(neitig). Dalam perkembangan penerbangan dalam negeri, para penumpang tidak banyak berbuat jika mengalami keterlambatan mereka hanya pasrah menerima saja apa yang diputuskan oleh maskapi penerbangan, menganggap hal yang wajar, perusahaan penerbangan selalu beralasan bahwa penundaan jadwal penerbangan dikarenakan alasan teknis pesawat demi keselamatan dan keamanan penerbangan. Dalam sejarah penerbangan di negeri ini tidak banyak perkara di pengadilan yang berkaitan dengan keterlambatan penerbangan.

\section{Upaya Hukum Ditempuh oleh Penumpang yang Mengalami Kerugian pada Bandara Sultan Hasanuddin Makassar?}

a. Ganti dalam hal terjadi kecelakaan pesawat

Mengenai besarnya ganti rugi sehubungan dengan luka-luka atau meninggalnya penumpang di atur dalam pasal 30 OPU 1939 yang menyatakan (1) Pada pengangkutan penumpang tanggungjawab pengangkut terhadap tiap-tiap penumpang atau terhadap keluarganya seluruhnya yang disebut dalam pasal 24 ayat (2), dibatasi sampai jumlah 12.500 gulden. Bila ganti rugi ditetapkan sebagai bunga, maka jumlah uang pokok yang dibungakan itu tak boleh melebihi jumlah tersebut di atas. Akan tetapi penumpang dapat mengadakan perjanjian khusus dengan pengangkut untuk meninggikan batas tanggung-jawab itu".

Dalam perkembangan kegiatan transportasi udara niaga ketentuan Pasal 30 Ordonansi Pengangkutan Udara 1939 tersebut telah diubah dengan Undang-Undang Nomor 15 Tahun 1992 tentang Penerbangan dan Peraturan Pemerintah Nomor 40 Tahun 1995 Tentang Pengangkutan Udara, yang diatur pada Pasal 43 Peraturan Pemerintah Nomor 40 Tahun 1995 yang menyatakan:

1) Santunan untuk penumpang yang meninggal dunia karena kecelakaan pesawat udara ditetapkan sebesar Rp 40.000.000,00 (empat puluh juta rupiah).

2) Santunan untuk penumpang yang menderita luka karena kecelakaan pesawatudara atau sesuatu peristiwa di dalam pesawat udara atau selama waktu antara embarkasi dan debarkasi berlangsung, ditetapkan sampai dengan setinggi- tingginya Rp 40.000.000,00 (empat puluh juta rupiah).

3) Santunan ganti rugi bagi penumpang yang menderita cacat tetap karena kecelakaan pesawat udara ditetapkan berdasarkan tingkat cacat tetap yang dialami sampai dengan setinggi-tingginya Rp 50.000.000,00 (lima puluh juta rupiah).

Berdasarkan ketentuan di atas dapat dijelaskan bahwa, besarnya ganti kerugian bagi penumpang yang meninggal dunia, mengalami luka-luka, dan mengalami 
cacad tetap. Adapun besarnya nilai santunan ganti rugi sebesar-besarnya adalah Rp. 40.000.000,00 (empat puluh juta rupiah) untuk korban meninggal dunia atau korban yang mengalami luka-luka, sedangkan untuk korban yang mengalami cacad tetap nilai ganti kerugiannya sebesar Rp. 50.000.000,00 (lima puluh juta rupiah). Jumlah ganti kerugian ini wajib dibayar oleh perusahaan pengangkutan udara. Jika dilihat dari jumlah nilai ganti kerugian di atas sungguh sangat kecil sekali sangat tidak memadai, oleh karena itu perlu dilakukan peninjauan kembali atas besaran ganti rugi tersebut. Perlu dilakukan peninjauan terhadap ketentuan mengenai ganti rugi ini didasari pertimbangan bahwa Peraturan Pemerintah No 40 Tahun 1995, sudah lama dan tidak cocok lagi dengan waktu saat ini.

Dalam praktik pemberian santunan atau ganti rugi khususnya untuk korban yang meninggal dunia oleh maskapai penerbangan dibayar jauh lebih besar dari ketentuan peraturan perundang-undangan, besar nominal ganti kerugiannya di atas seratus juta rupiah. Besarnya nilai santunan yang diberikan oleh perusahaan penerbangan kepada korban atau ahli warisnya ternyata tidak sama antara satu perusahaan dengan perusahaan lainnya.

\section{b. Ganti Rugi Terhadap Keterlambatan Penerbangan}

Berbeda dengan tanggung jawab perusahaan pengangkutan udara terhadap penumpang berkenaan dengan kematian atau luka-luka penumpang dan tanggung jawab terhadap barang, yang mana undang-undang menentukan besaran nilai ganti ruginya, sedangkan tanggung jawab perusahaan pengangkutan udara terhadap kelembatan tidak ditentukan secara limitative besarnya nilai ganti rugi.

Peraturan Pemerintah Nomor 40 Tahun 1995 hanya menyatakan bahwa perusahaan pengangkutan udara wajib untuk memberikan pelayanan kepada penumpang selama terjadinya penundaan penerbangan sebagaimana dinyatakan dalam pasal Pasal 40, Perusahaan angkutan udara niaga wajib memberikan pelayanan yang layak terhadap setiap calon pengguna jasa angkutan udara. Selanjutnya dalam Pasal 41 dinyatakan: (1) Perusahaan udara niaga wajib mengutamakan pengangkutan calon penumpang atau barang yang pemiliknya telah melaksanakan kewajibannya sesuai perjanjian pengangkutan yang disepakati. (2) Dalam hal terjadi keterlambatan atau penundaan dalam pengangkutan karena kesalahan pengangkut, perusahaan angkutan wajib memberikan pelayanan yang layak kepada penumpang atau memberikan ganti rugi atas kerugian yang secara nyata dialami oleh penumpang atau pemilik barang.

Dalam penjelasannya dinyatakan yang dimaksud dengan memberikan pelayanan yang layak dalam ketentuan ini adalah memberikan pelayanan dalam batas kelayakan sesuai kemampuan pengangkut kepada penumpang selama menunggu keberangkatan antara lain berupa penyediaan tempat dan konsumsi secara layak selama menunggu keberangkatan atau mengupayakan mengalihkan angkutan ke perusahaan angkutan udara niaga lainnya sesuai perjanjian pengangkutan yang disepakati. 


\section{c. Perlindungan Asuransi bagi penumpang}

Secara yuridis asuransi penerbangan pertama kali diatur dalam UndangUndang Nomor 33 Tahun 1964 Tentang Dana Pertanggungan Wajib Kecelakaan Penumpang, yaitu pada Pasal 3 yang menyatakan: (1) a. Tiap penumpang yang sah dari kendaraan bermotor umum, kereta-api, pesawat terbang, perusahaan penerbangan nasional dan kapal perusahaan perkapalan/pelayaran nasional, wajib membayar iuran melalui pengusaha/pemilik yang bersangkutan untuk menutup akibat keuangan disebabkan kecelakaan penumpang dalamperjalanan. c. Iuran wajib tersebut pada sub a diatas digunakan untuk mengganti kerugian berhubung dengan: I. kematian, dan II. cacat tetap, akibat dari kecelakaan penumpang.

d. Penyelesaian Sengketa Konsumen

Dalam Undang-Undang Nomor 8 Tahun 1999 pada Pasal 45 dinyatakan:

(1) Setiap konsumen yang dirugikan dapat menggugat pelaku usaha melalui lembaga yang bertugas menyelesaikan sengketa antara konsumen dan pelaku usaha atau melalui peradilan yang berada di lingkungan peradilan umum.

(2) Penyelesaian sengketa konsumen dapat ditempuh melalui pengadilan atau di luar pengadilan berdasarkan pilihan sukarela para pihak yang bersengketa.

(3) Penyelesaian sengketa di luar pengadilan sebagaimana dimaksud pada ayat (2) tidak menghilangkan tanggungjawab pidana sebagaimana diatur dalam Undang-undang.

(4) Apabila telah dipilih upaya penyelesaian sengketa konsumen di luar pengadilan, gugatan melalui pengadilan hanya dapat ditempuh apabila upaya tersebut dinyatakan tidak berhasil oleh salah satu pihak atau oleh para pihak yang bersengketa.

\section{e. Penyelesaian sengketa konsumen di luar pengadilan}

Ketentuan mengenai penyelesaian Sengketa di luar Pengadilan, diaturpada Pasal 47 yang menyatakan: Penyelesaian sengketa konsumen di luar pengadilan diselenggarakan untuk mencapai kesepakatan mengenai bentuk dan besarnya ganti rugi dan/atau mengenai tindakan tertentu untuk menjamin tidak akan terjadi kembali atau tidak akan terulang kembali kerugian yang diderita oleh konsumen.

Dalam memilih penyelesaian sengketa konsumen di luar pengadilan dapat dilakukan melalui beberapa model penyelesaian sengketa, diantranya melalui Alternatif Resolusi Masalah (ARM) di Badan Penyelesaian Sengketa Konsumen, Lembaga Perlindungan Konsumen Swadaya Masyarakat, atau melalui Direktorat Perlindungan Konsumen atau lokasi-lokasi lain baik untuk kedua belah pihak yang telah disetujui.

\section{f. Penyelesaian melalui Badan Penyelesaian Sengketa Konsumen (BPSK)}

BPSK adalah institusi non struktural yang memiliki fungsi sebagai "institusi yang menyelesaikan permasalahan konsumen diluar pengadilan secara murah, cepat dan sederhana". Badan ini sangat penting dibutuhkan di daerah dan kota di seluruh 
Indonesia.

Anggota-anggotanya terdiri dari perwakilan aparatur pemerintah, konsumen dan pelaku usaha. Konsumen yang bermasalah terhadap produk yang dikonsumsi akan dapat memperoleh haknya secara lebih mudah dan efisien melalui peranan BPSK.

Selain itu bisa juga menjadi sebuah akses untuk mendapatkan infomasi dan jaminan perlindungan hukum yang sejajar baik untuk konsumen maupun pelaku usaha. Dalam menangani dan mengatur permasalahan konsumen, BPSK memiliki kewenangan untuk melakukan pemeriksaan atas kebenaran laporan dan keterangan dari para pihak yang bersengketa. Tagihan, hasil test lab dan bukti-bukti lain oleh konsumen dan pengusaha dengan mengikat penyelesaian akhir.

Tugas-tugas utama BPSK:

1. Menangani permasalahan konsumen melalui mediasi, konsiliasi atau arbitrasi;

2. Konsultasi konsumen dalam hal perlindungan konsumen;

3. Mengontrol penambahan dari bagian-bagian standarisasi;

4. Memberikan sanksi administrasi terhadap pengusaha yang menyalahi aturan;

E. KESIMPULAN DAN SARAN

1. Kesimpulan

Berdasarkan hasil penelitian dan pembahasan maka ditarik beberapa kesimpulan, yaitu sebagai berikut:

1. Dalam hukum positif Indonesia terdapat beberapa peraturan perundangundangan yang memberikan perlindungan hukum terhadap penumpang transportasi udara niaga berjadwal,peraturan tersebut antara lain UndangUndang Nomor 15 Tahun 1992 Tentang Penerbangan; Ordonansi Penerbangan 1939 atau OPU 1939;Peraturan Pemerintah Nomor 40 Tahun 1995 Tentang Angkutan Udara; Peraturan Pemerintah Nomor 3 Tahun 2001 Tentang keamanan dan keselamatan Penerbangan; Undang-Undang Nomor 8 Tahun 1999 Tentang Perlindungan Konsumen.

2. Terhadap penumpang transportasi udara yang merasa atau mengalami kerugian dapat mengajukan gugatan atau klaim kepada perusahaan penerbangan, penyelesaian gugatan atau sengketa dapat ditempuh melalui dua jalur yaitu jalur pengadilan dan jalur di luar pengadilan. Kedua model penyelesaian sengketa tersebut diakui di dalam Undang-Undang Nomor 8 Tahun 1999 Tentang Perlindungan Konsumen. Konsumen bebas untuk memilih model penyelesaian sengketanya.

\section{Saran - Saran}

Dalam rangka untuk lebih memberikan perlindungan hukum terhadap pengguna jasa transportasi maka perlu dilakukan peninjauan kembali terhadap instrumen-instrumen hukum yang mengatur tentang kegiatan penerbangan, sebab produk-produk hukum yang ada sudah tidak sesuai lagi dengan perkembangan 
jaman. Dilihat dari perspektif historis instrumen hukum yang mengatur tentang penerbangan sudah sangat lama misalnya Ordonansi Pengangkutan Udara 1939 yaitu di buat pada Tahun 1939 pada masa colonial Belanda yang tentu saja materi dan substansi peraturan sudah tidak sesuai lagi dengan kondisi saat ini. Selain faktor usia peraturan hal mendesak untuk dilakukan perbaikan adalah aturan mengenai jumlah nilai ganti rugi, sebab nilai ganti rugi yang ditentukan di dalam undangundang sangat kecil, kemudian undang-undang tidak secara tegas memberikan sanksi hukum bagi maskapai penerbangan yang melakukan penundaan penerbangan. Untuk diperlukan aturan sanksi bagi maskapai penerbangan yang menunda penerbangan tanpa alasan yang jelas yang dibenarkan oleh undangundang.

\section{Daftar Pustaka}

Ichsan, Achmad. Hukum Dagang, Jakarta; Pradnya Paramita. 1993.

Kamaluddin, Rustian. Ekonomi Transportasi: Karekteristik, Teori Dan Kebijakan, Ghalia Indonesia, Jakarta. 2003.

Kartaatmadja, Komar. Beberapa Masalah Dalam Penerapan ADR Di Indonesia Dalam Prospek dan Pelaksanaannya Arbitrase di Indonesia, Bandung:PT Citra Adiyta Bhakti. 2001.

Khairandy, Ridwan. Tanggung Jawab Pengangkut dan Asuransi Tanggung Jawab Sebagai Instrumen Perlindungan Konsumen Angkutan Udara, Jurnal Hukum Bisnis Vol 25, Jakarta. 2006.

Menurut Hukum Udara Indonesia, Jakarta: Jurnal Hukum Bisnis Vol 25. 2006.

Muhammad, Abdulkadir. Arti Penting dan Strategis Multimoda Pengangkutan Niaga di Indonesia, Dalam Perspektif Hukum Bisnis di Era Globalisasi Ekonomi, Yogyakarta: Penerbit Genta Press. 2007.

Hukum Pengangkutan Niaga, Bandung: Citra Aditya Bhakti, 1998. Hukum Perikatan, Bandung: Citra Aditya Bhakti. 1987.

Nasution. AZ. Pengantar Hukum Perlindungan Konsumen. Jakarta. Penerbit Daya Widya. 1999.

Ningrum, Lestari. Usaha Perjalanan Wisata Dalam Perspektif Hukum Bisnis, Bandung: Citra Aditya Bakti. 2004.

Purwosutjipto, HMN. Pengertian Pokok-Pokok Hukum Dagang Indonesia 3: Hukum Pengangkutan, Jakarta: Penerbit Djambatan. 2003.

Rahardjo, Satjipto. Ilmu Hukum, Bandung: Alumni. 1986.

Soekanto, Soerjono. Pengantar Penelitian Hukum. Jakarta: Penerbit Universitas Indonesia. 2006.

-Mengenal Antropologi Hukum, Bandung: Penerbit Alumni. 1979. 
Wiradipradja, E. Saefullah. Tanggung Jawab Perusahaan Penerbangan Terhadap Penumpang.

\section{Peraturan Perundang-undangan}

Undang-Undang Nomor 15 Tahun 1992 Tentang Penerbangan

Undang-Undang Nomor 8 Tahun 1999 Tentang Perlindungan Konsumen

Peraturan Pemerintah Nomor 40 Tahun 1995 Tentang Angkutan Udara

Ordonansi Penerbangan Udara 1939 Tentang Pengangkutan Udara

Undang-Undang Nomor 33 Tahun 1964 Tentang Dana Pertanggungan Wajib KecelakaanPenumpang 